\title{
Connect vs. conquer? CEO gender and implicit motives
}

Julie Brueckner 1, Janine Bosak 1, and Jonas W. B. Lang 2

1 Dublin City University, 2 Ghent University and University of Exeter

Author Preprint

Article was accepted for publication on 20-Aug-2020

To appear in:

Brueckner, J., Bosak., J., \& Lang, J. W. B. (in press). Connect vs. conquer? CEO gender and implicit motives. In Chrobot-Mason, D., Sawyer, K., \& Hays-Thomas, R. (Eds). Women leaders [Special issue]. Journal of Managerial Psychology, doi:10.1108/JMP-01-2019-0061 


\begin{abstract}
Purpose - This study examined gender differences in CEOs' expression of implicit achievement, power, and affiliation motivation. Building on the role congruity account of sex differences and similarities in motivation and existing literature on implicit motives, the study tested whether female CEOs would express higher affiliation motivation than male CEOs and similar levels of achievement motivation. In addition, gender differences in power motivation were explored.
\end{abstract}

Design/methodology/approach - The study used propensity score matching to generate a comparable sample of male and female CEOs from publicly-traded companies. Subsequently, the authors content-coded CEO letters from annual reports using Winter's (1994) manual for scoring motive imagery in running text.

Findings - Overall, CEOs expressed more achievement and power motivation than affiliation motivation. Comparisons between male and female CEOs showed that female CEOs expressed lower power and higher affiliation motivation than male CEOs.

Research limitations/implications - By integrating implicit motive theory with social role theory and the role congruity account of motivation, this study provides a theoretical framework and novel demonstration that understanding social roles and gender roles can lend insights into motive expression by CEOs.

Originality/value - The study uses established theory and a validated scoring method in a novel way by analyzing implicit motives from CEO letters, a critical communication channel in the CEO-shareholder relationship. In doing so, this study adopts a socio-cultural perspective. Informed by the role congruity account of motivation, the study demonstrates the importance of social roles and gender roles for motivational displays.

Keywords Gender; Sex; Motivation; Achievement; Power; Affiliation; CEO; Leadership Paper type Research Paper 


\section{Connect vs. conquer? CEO gender and implicit motives}

Organizational researchers typically argue that Chief Executive Officers (CEOs) significantly influence the fate of organizations: As organizations' ultimate decision-makers, they can potentially affect business processes, strategy, and shape organizational performance (Hambrick \& Quigley, 2014)—for better or for worse. Researchers have, therefore, long been interested in the motivation of leaders and in its influence on CEO behavior and decisions (Kanfer et al., 2017; Runge \& Lang, 2019). One prominent line of research has focused on studying implicit achievement, power, and affiliation motives as antecedents of political (e.g., House et al., 1991; Spangler \& House, 1991; Winter, 1987) and organizational leadership (e.g., Jacobs \& McClelland, 1994; McClelland \& Boyatzis, 1982; Winter, 1991a). Typically described as individuals' relatively enduring preferences for specific classes of affectively charged incentives, implicit motives (IM) form long-term behavioral tendencies (Brunstein et al., 1998; Schultheiss \& Brunstein, 2010). Research has found some evidence that IM relate to career and leadership outcomes (Apers et al., 2019; Delbecq et al., 2013; Lang et al., 2012). Although most leadership scholars believe that motivation is an important element in leadership, research has not yet systematically investigated the role of gender in the IM of CEOs.

To date, none of the studies that the authors are aware of and that researched IM in the context of CEO-leadership (e.g., Chusmir \& Azevedo, 1992; De Hoogh et al., 2005; Delbecq et al., 2013; Kirkpatrick et al., 2002; Veenstra, 2013) has explicitly examined gender. Although recent meta-analytic findings suggest a positive relationship between women's leadership and firm-performance (Hoobler et al., 2018), women are still underrepresented in top management, especially as CEOs (Catalyst, 2020). This imbalance in leadership role occupancy and the resulting use of predominantly male samples in research are contributing factors as to why knowledge about gender and leaders' IM has been described as fragmented 
(Duncan \& Peterson, 2010; Pang \& Baumann, in press). In addition, research investigating the relationship between motives and gender in the leadership context has largely focused on explicit rather than implicit motivational constructs (e.g., Bark et al., 2016; Elprana et al., 2015; Schuh et al., 2014). Moreover, those few studies that have examined the role of gender in IM (e.g., Denzinger et al., 2016; Pang \& Schultheiss, 2005; Schultheiss \& Brunstein, 2001) have neither investigated leaders nor shown consistent results. A recent meta-analysis found that women-in-general scored higher on affiliation motivation than men-in-general but similarly on achievement and power motivation (Drescher \& Schultheiss, 2016). In contrast, other research found that men score higher on achievement and power motivation than women (e.g., Denzinger et al., 2016). Thus, to date, knowledge is limited as to whether gender effects will appear in executive leadership roles in which women are scarce and in which female CEOs might adapt their motivational expressions to fit the masculine requirements of the leader role and/or their female gender role. This gap aligns with Duncan and Peterson's (2010) call for more systematic "research on women business leaders [...] to enhance our understanding of how [implicit] motives relate to [...] contemporary leaders" (p. 43).

To respond to this call and to address the existing gap in the literature, this study investigates gender differences in the IM of executive leaders. In doing so, this study integrates research on IM and the role congruity perspective of men, women, and motivation (Diekman \& Eagly, 2008), in addition to other theories. The present study also addresses some limitations of prior research by systematically examining the prevalence of IM among men and women using a propensity-matched, gender-balanced sample of stock market company CEOs. 


\section{Implicit Motives}

In studying motivation through a personality lens, McClelland et al. (1989) theorized that people's behavior is guided and shaped by individual differences in people's implicit motivational needs. These IM are thought to develop in early, pre-verbal childhood through affective experiences and socialization processes (McClelland \& Pilon, 1983). IM are typically described as "relatively stable individual characteristic[s] that energize and direct behavior" (Hoffman et al., 2011, p. 351). The literature generally differentiates the achievement, power, and affiliation motives (McClelland et al., 1989), also called the Big Three (Kehr, 2004). The achievement motive concerns people's desire to attain a standard of excellence, the power motive relates to people's wish to exert influence over others and receive recognition, and the affiliation motive refers to people's need for deep, meaningful relationships and interpersonal friendliness (Lang et al., 2012; McClelland et al., 1989).

Motivation is conceptualized as encompassing both conscious (explicit) and unconscious (implicit) elements. These elements are thought to be reflective of two different motivational systems that predict different behavioral outcomes (McClelland et al., 1989). Explicit motives (EM) are argued to predict respondent behaviors regarding people's conscious self-image, whereas IM are argued to predict operant behaviors and long-term behavioral tendencies. Operant behaviors, in turn, are described to be particularly important in unstructured situations and were shown to be relevant for leadership and managerial success (Schultheiss \& Brunstein, 2010). EM are typically assessed using self-report measures. Thereby, EM are sensitive to biases, such as social desirability, and, hence, do not reflect individuals' underlying motivational preferences. IM, however, are typically assessed using time-consuming content-coding methods (Schultheiss \& Pang, 2007). By researching IM rather than EM, this study, thus, captures potential gender differences in what have been argued to be important antecedents to leadership (Delbecq et al., 2013). Given that IM are 
predictive of long-term leadership tendencies, understanding their manifestation is critical (Schultheiss \& Brunstein, 2010).

Past research has studied the impact of IM on successful leadership (De Hoogh et al., 2005; Winter, 1991a). Studies showed that achievement motivation was linked to business success and leader emergence (e.g., Sorrentino, 1973; Winter, 2010a). Power motivation was associated with charisma, effectiveness, and advancement into upper managerial positions (e.g., House et al., 1991; McClelland \& Boyatzis, 1982; Spangler \& House, 1991) and is largely considered to be the great motivator of leadership (McClelland \& Burnham, 2003). Affiliation motivation was related to managerial/team performance (e.g., Cornelius \& Lane, 1984; Kirkpatrick et al., 2002) and is believed to be increasingly important in the context of changing leadership demands, such as the growing need for more collaboration, networking, and cooperation (Spangler et al., 2014; Steinmann et al., 2015).

\section{Implicit Motives, Gender, and Leadership}

In theorizing about gender differences and similarities in implicit power, achievement, and affiliation motives, this research adopts a social role perspective. According to social role theory (Eagly et al., 2000), the gendered division of labor in society fosters genderdifferentiated attributes as well as gender stereotypes. The content of gender roles is argued to reflect the two fundamental dimensions of agency and communion (Bakan, 1966). Agency is typically described as striving for achievement and influence, and communion as comprising a concern for the interests of others (Locke, 2015; Wojciszke et al., 2009). Men, more than women, are believed to be agentic (e.g., assertive, dominant), and women, more than men, are believed to be communal (e.g., caring, warm; Eagly \& Karau, 2002).

Traditional beliefs about leaders are predominantly masculine in their emphasis on agentic qualities (Powell et al., 2002). This emphasis on masculinity is unsurprising since the majority of leaders throughout history have been male. However, over the years, the 
masculine construal of leadership has decreased (e.g., Kunkel et al., 2003), with contemporary managerial ideals increasingly accentuating feminine leadership qualities (see Duehr \& Bono, 2006; Eagly, 2007; Powell et al., 2002). This is partly due to a growing number of women in leadership and a shift towards more feminine leadership styles. Nevertheless, leadership concepts continue to be "strongly infused with cultural masculinity" (Eagly \& Antonakis, 2015, p. 574) and thus emphasize more agentic qualities than communal ones (Badura et al., 2018; Koenig et al., 2011). For instance, recent research by Vial and Napier (2018) demonstrated that stereotypically masculine, agentic traits are still seen as critically advantageous. They found that "both men and women viewed agentic traits as more important than communal traits to be a successful leader" (p. 1). In line with this predominately agentic view of leaders found in prior research, De Hoogh et al. (2005) observed that CEOs scored lowest for their expressions of affiliation motivation and highest for achievement and power motivation. Other IM studies in a managerial context demonstrate similar differences in the mean scores for these three motives (e.g., Kirkpatrick et al., 2002).

In general, congruence with social roles is argued to be a critical motivational force as "specific roles afford particular opportunities to pursue goals, and individuals are more likely to seek and attain the goals that are afforded by their roles" (Diekman \& Eagly, 2008, p. 443). This implies that specific social roles facilitate different motivations by creating distinct possibilities for individuals to express motivations. Given that research has found that agentic traits are perceived as important determinants of leadership effectiveness (e.g., Koenig et al., 2011), this study proposes that the leadership role affords the display of agentic motives (i.e., achievement, power) rather than communal motives (i.e., affiliation).

HIa. CEOs more frequently express achievement motivation in their letters than affiliation motivation. 
H1b. CEOs more frequently express power motivation in their letters than affiliation motivation.

Social role theory postulates that gender role beliefs induce role-consistent motives and behavior (Eagly, 2000). Scholars have argued that the display of role-congruent motives likely fosters rewards, whereas the display of role-incongruent motives likely yields penalties. To gain rewards and avoid costs, a combination of external and internal mechanisms might direct men's and women's motivations towards achieving congruence with their social roles (e.g., the leadership role) and their respective gender roles (Diekman \& Eagly, 2008). External mechanisms include, for example, a reaction to environmental affordances or interactions with people who have internalized gender-stereotypic beliefs (Diekman \& Eagly, 2008; Geis, 1993). Internal mechanisms, for example, relate to leaders' self-concepts or self-efficacy beliefs. According to Diekman and Eagly (2008), these mechanisms can unravel either consciously (e.g., through impression management) or unconsciously.

Concerning external mechanisms, researchers have argued that gender roles affect behaviors through the beliefs, subjective norms, and hence endorsement or rejection provided by their social environment (e.g., Ridgeway \& Correll, 2004). Thus, individuals may "generally tend to seek to fulfill basic human needs by gender-normative means" (Diekman \& Eagly, 2008, p. 437) as a result of differential expectations directed towards male and female CEOs — a phenomenon known as gender role spillover (Eagly et al., 1992; Gutek \& Morasch, 1982). Differences in expectations may result in variations between men's and women's behaviors or motivational expressions. This implies that although men and women in the same occupational role may engage in similar behavior, and thus be perceived as less gender stereotypic (e.g., Bosak et al., 2012; Eagly et al., 1992), they might still differ in their expression and approaches to meet their motivational needs in a way that is congruent with 
traditional gender role stereotypes. Specifically, Eagly et al. (1992) argue that "gender roles may continue to have some importance in organizational settings, with the consequence that women are regarded not as generic managers, but as female managers and men are regarded as male managers" (p. 5).

Although research shows that, in general, women and men are seen as equally effective leaders (e.g., Paustian-Underdahl et al., 2014), under certain conditions, biased perceptions in favor of one gender persist (e.g., Bosak et al., 2018). For instance, senior women leaders might be seen as particularly competent, given their success in a highly masculine sex-typed role (e.g., Rosette \& Tost, 2010). However, women in higher-level leadership roles can also "encounter more prejudice because of the greater stereotypical mismatch between women and leadership" (Koenig et al., 2011, p. 635), especially for displaying dominance and control (e.g., Rudman et al., 2012; Williams \& Tiedens, 2016). One strategy that women may utilize to enhance their success in leadership roles is, thus, to complement their agentic repertoire with communal behaviors (e.g., Shackelford et al., 1996; Watson, 1988). Yet, regardless of the external mechanisms that might direct individuals to consciously or unconsciously blend agentic and communal behavior, gender continues to influence how individuals enact their social identities in a given context (Holmes, 2008) as a result of internal mechanisms.

Concerning internal mechanisms, scholars have argued that individuals internalize gender-stereotypical beliefs and goals into their self-concept (Bussey \& Bandura, 1999). Regarding communion, women are thought to have a more relational self-construal than men (Gardner \& Gabriel, 2004). As having close connections with others represents a stronger motivating force for women than for men, women's attention to the relational opportunities afforded by roles is likely amplified (Diekman \& Eagly, 2008). In support of this rationale, a meta-analysis found that female doctors expressed more communal behaviors than their male 
colleagues (Roter et al., 2002). Moreover, a meta-analysis by Twenge (1997) found that women continue to report communal, feminine-stereotyped traits to a greater degree than men as they likely embrace a more communal identity than their male counterparts. Regarding agency, the same meta-analysis by Twenge (1997) found that, over time, men and women became more similar in their self-report measures of agentic, masculine-stereotyped traits. Indeed, women increasingly reported these traits as part of their self-concept. These findings suggest that internalized gender norms about the display of agentic and communal IM might extend to specific social roles, such as the leadership role.

IM scholars also proposed that gender role socialization plays a crucial part in the way men and women express IM (Drescher \& Schultheiss, 2016; Pang \& Baumann, in press; Pang $\&$ Schultheiss, 2005). The display of IM is likely sensitive to the social context in which they occur and has been described to be susceptible to prevalent norms about gender roles (Duncan \& Peterson, 2010). Longitudinal research by Veroff et al. (1980) found that, for achievement motivation, men remained stable, and women increased over time. Researchers attributed this increase in women's achievement motivation to greater female participation in the workforce and a corresponding change in both women's internalized gender beliefs and gender norms for working women (Duncan \& Peterson, 2010). For power and affiliation motivation, Veroff et al. (1980) found that women remained relatively stable over time. In contrast, men increased in power but decreased in affiliation motivation. Veroff et al. (1980) attributed this difference to men seeking more power at work rather than in the domestic domain. These findings suggest that men's and women's achievement motivations have converged, whereas their power and affiliation motivations likely have not. Other research by Schultheiss and Brunstein (2001) found that affiliation and power motivation were negatively correlated for women but not men. This indicates that "for women, the need for positive, harmonious relationships and the need to have impact may conflict with each other and thus 
be mutually exclusive to some extent” (Schultheiss \& Brunstein, 2001, p. 82). In addition, psychoendocrinological studies have associated power with the male sex hormone, testosterone, and affiliation with the female sex hormone, progesterone (Schultheiss, 2013). Achievement has not been clearly associated with sex hormones.

In summary, both men and women might (consciously or not) be inclined to express their motives in congruence with their social role and their gender role to achieve intra- and interpersonal rewards and avoid punishment. For affiliation motivation, given the evidence of greater affiliation motivation in women than men (Drescher \& Schultheiss, 2016) and of greater communion displayed and reported by women than men (Roter et al., 2002; Twenge, 1997), this study hypothesizes that female CEOs will express more affiliation motivation than male CEOs. For achievement motivation, given the evidence of similar levels of achievement motivation in women and men (Drescher \& Schultheiss, 2016) and an observed convergence in self-ascribed agentic traits for the sexes (Twenge, 1997), this research expects male and female CEOs to express similar levels of achievement motivation. For power motivation, the theoretical assumptions and evidence are rather mixed. Psychoendocrinological studies suggest that men could score higher than women, whereas the role congruity framework suggests either a null effect (due to the constraints of the social role) or that men will score higher than women (due to the anticipated backlash against women who violate the female gender norm via power expression). In addition, the argument that female CEOs are particularly agentic would suggest that women may score higher in power motivation than men. This study, therefore, does not state an explicit hypothesis for power motivation but rather explores gender differences for this motive. Hence:

H2. Female CEOs more frequently express affiliation motivation in their letters than male CEOs. 


\section{Method}

\section{Sampling and Procedure}

CEOs were sourced from Standard \& Poor's (S\&P) Execucomp (2019) database. This database provides executive information on organizations belonging to the S\&P Composite 1500 Index. The authors collected annual reports of female CEOs corresponding to the first available year of their CEO tenure. Then, the authors specified certain inclusion criteria: (1) the annual report must include a CEO letter; and (2) the letter must be attributable to and signed by one single person, i.e., the CEO. Of all listed female CEOs in 2014, 45 met the inclusion criteria. Due to the imbalanced ratio of female to male CEOs, the authors created a subsample of 400 male CEOs who met the inclusion criteria and then applied a propensity score method to generate a gender-balanced sample of comparable CEOs.

A propensity score is commonly defined as "the probability of receiving a treatment based on measured covariates" (Thoemmes, 2012, p. 3). This tool for improving internal validity allows the study of an equal number of male and female CEOs (Connelly et al., 2013). By estimating the likelihood of a person falling within the "treatment" condition (i.e., female CEOs) based on certain background characteristics, the study can match these participants to individuals from the "control" condition (i.e., male CEOs) who have similar values (Connelly et al., 2013). Consequently, a total of 45 female CEOs were matched with 45 male CEOs on the following predefined background characteristics: (1) industry; (2) CEO age; and (3) CEO tenure.

\section{Motive Assessment}

As IM are not consciously accessible, they cannot be investigated with self-report questionnaires (Schultheiss \& Pang, 2007). Instead, IM need to be measured indirectly, for example, with the help of reliable content-coding techniques (Lang, 2014). Therefore, this study utilizes Winter's second-generation scoring manual for text analysis (1994) to code 
CEOs' motives. As summarized by Duncan and Peterson (2010), the manual represents a validated and reliable tool (Schultheiss \& Pang, 2007) that (1) enables raters to score all motives in one go; (2) can be used for any kind of non-technical, written material including archival data (e.g., speeches and letters); (3) can be equally applied to male and female participants as it uses the same scoring definitions for both sexes; and (4) allows measuring IM at a distance (Winter, 1991b). Thereby, the manual has opened up new possible areas for research. Since its development, it has been applied to a variety of settings and materials (Schultheiss \& Brunstein, 2010), such as CEO vision statements (Kirkpatrick et al., 2002) or presidential speeches (Winter, 1987). Due to its extensive predictive validity, the Winter manual has become a standard content-coding approach in the field of motivation research (Duncan \& Peterson, 2010; Pang \& Schultheiss, 2005; Schultheiss \& Pang, 2007). The present study extends its application to examine CEO letters. By studying archival data of U.S.-based stock market companies, this research benefits from data that is highly consistent and uniform. The CEO letter is an integral, motive-laden part of many annual reports. It has been described as being among the most important communication channels in the CEOshareholder relationship as it represents one of the few opportunities for CEOs to directly address all company owners (Amernic \& Craig, 2007).

Leaders' IM were analyzed in a blind triple-coding process by four different raters. Raters underwent extensive training in the application of the manual. Prior to the scoring process, raters completed expert calibration sets with a category agreement of above .85 , according to Winter's (1994) category agreement formula (Kirkpatrick et al., 2002). The identity of the $\mathrm{CEO}$ was masked to rater $\mathrm{B}$, rater $\mathrm{C}$, and rater $\mathrm{D}$, who had no prior information regarding CEOs' gender, ethnicity, age, or physical appearance. Rater A and rater B coded all CEO letters, whereas rater $\mathrm{C}$ and rater $\mathrm{D}$ each coded half of the CEO letters. Discrepancies between the first and second coders were resolved through the standard procedure of 
discussion and reaching consensus (e.g., Kirkpatrick et al., 2002; Schultheiss \& Pang, 2007). If no agreement was reached, the average of both coders' total score for achievement, power, or affiliation was used for further analysis. Rater B independently coded all letters discussed

by rater A and C. Rater D independently coded all letters discussed by rater A and B. This way, each letter was independently coded by two raters blind to the hypotheses and CEO characteristics. To estimate inter-rater reliability, the study followed examples in the literature (Apers et al., 2019; Koo \& Li, 2016) and assessed intraclass correlations (ICC $(2, k)$; see Shrout \& Fleiss, 1979). Coders demonstrated sufficient inter-rater reliabilities (Koo \& Li, 2016) of .921 for achievement and .779 for power, and .651 for affiliation between the average of the 42 letters discussed with Rater $\mathrm{C}$ and the 42 independently coded letters of Rater B as well as .836 for achievement, .960 for power, and .761 for affiliation between the average of the 48 letters discussed with Rater B and the 48 independently coded letters of Rater D. As ICCs were sufficiently high, codings of the first, second, and third rater were averaged to obtain the final IM scores.

\section{Measures}

Implicit motives. Achievement, power, and affiliation motives were scored according to the guidelines presented in Winter's (1994) manual for text analysis. For example, a motive category may only be scored once per scoring unit (i.e., sentence), unless it is interrupted by the expression of a different motive category. If participants display more than one motive category at the same time, the stronger motive is coded. Moreover, a particular motive may not be scored in two consecutive sentences, unless it is interrupted by a different motive. Instead, an intermission of one sentence needs to be maintained in case of two reoccurring motives of the same kind. A coding of 1 is assigned to each time achievement, power, or affiliation imagery is scored as present versus absent. Final motive scores for each CEO letter represent the total sum scores for each motive category. Final scores were 
determined by adding the number of times a motive category was marked as present. To provide examples of the Winter (1994) coding methodology, a sentence like "We strive to be the best." was coded as achievement, "We want to conquer the market." was coded as power, and "We deeply care about our customer's happiness." was coded as affiliation. For replication purposes, please refer to Winter (1994). Typically, raw IM counts co-vary with the length of written material, with women often producing longer written materials than men (Schultheiss \& Brunstein, 2001). The study followed standard procedure of reducing covariation by presenting IM as frequencies of motives per 1,000 words, using the formula recommended by Winter $(1994$; (score $\square \square$ word count $) \times 1,000)$.

Sex. Information regarding CEOs' sex (male, female) was derived from S\&P's Execucomp database and double-checked by screening CEOs' first names.

Word count. The length of CEO letters $(M=1,230.70, S D=593.02$ words $)$ was determined by counting the number of words in its main body. Salutation phrases, additional boxes, and descriptions of figures or tables were neither included in the coding nor in determining the length of the document.

Control variables. A propensity score matching was used to derive comparable matched samples and to control for predefined background characteristics. By matching participants according to their (1) industry; (2) CEO age; and (3) CEO tenure, these characteristics were kept constant. This procedure reduces the likelihood that an effect is attributable to differences in, for example, prior leadership experience (Connelly et al., 2013). Industry membership is a crucial characteristic for identifying comparable organizations (Bhojraj \& Lee, 2002) in the S\&P Index. Fama and French (1997) developed an algorithm to group Standardized Industry Classification (SIC) codes presented in the S\&P Execucomp database into 12 different industries as follows: $1=$ Consumer Nondurables; $2=$ Consumer Durables; 3 = Manufacturing; 4 = Oil, Gas, and Coal Extraction and Products; $5=$ 
Chemicals and Allied Products; $6=$ Business Equipment; $7=$ Telephone and Television Transmission; $8=$ Utilities; $9=$ Wholesale, Retail, and Some Services (Laundries, Repair Shops); $10=$ Healthcare, Medical Equipment, and Drugs; $11=$ Finance; and $12=$ Other (French, 2019).

CEO age was accessed through the 2014 S\&P Execucomp database $(M=55.52, S D=$ 5.68 years). Age is an important determinant of prior management experience and, therefore, a possible confounding variable.

CEO tenure $(M=3.74, S D=4.06$ years $)$ represents the number of years a CEO is or was appointed in a respective company. For CEOs who were still in office in 2014, the study calculated tenure by subtracting the year in which the CEO was appointed from the year 2014.

\section{Preliminary Analyses}

Preliminary analyses of 90 CEOs (45 female) found that IM counts positively correlated with the length of the CEO letters. Specifically, all three motives correlated above $|0.15|$ with the word count, which marks the cut-off score for transformations as specified by Schultheiss and Pang (2007). Raw IM scores were, therefore, transformed into motive images per 1,000 words (Schultheiss \& Pang, 2007; Winter, 1994). The propensity-matched samples of men and women are similar in terms of CEOs' age $\left(M_{f}=55.82, S D_{f}=6.02\right.$ years; $M_{m}=$ $55.22, S D_{m}=5.36$ years; $\left.d=0.11\right)$, CEOs' length of tenure $\left(M_{f}=3.82, S D_{f}=4.24\right.$ years; $M_{m}$ $=3.67, S D_{m}=3.91$ years; $\left.d=0.04\right)$, and distribution of industries. Of the organizations led by female CEOs, $13.33 \%$ are in Consumer Nondurables; $4.44 \%$ in Consumer Durables; $15.56 \%$ in Manufacturing; 0\% in Oil, Gas, and Coal Extraction and Products; 2.22\% in Chemicals and Allied Products; $8.89 \%$ in Business Equipment; 2.22\% in Telephone and Television Transmission; $11.11 \%$ in Utilities; $11.11 \%$ in Wholesale, Retail, and Some Services (Laundries, Repair Shops); 2.22\% in Healthcare, Medical Equipment, and Drugs; 20\% in 
Finance; and $8.89 \%$ in other industries. Of the organizations led by male CEOs, $13.33 \%$ are in Consumer Nondurables; 0\% in Consumer Durables; 22.22\% in Manufacturing; 0\% in Oil, Gas, and Coal Extraction and Products; $2.22 \%$ in Chemicals and Allied Products; $13.33 \%$ in Business Equipment; 4.44\% in Telephone and Television Transmission; 8.89\% in Utilities; 6.67\% in Wholesale, Retail, and Some Services (Laundries, Repair Shops); 0\% in Healthcare, Medical Equipment, and Drugs; $17.78 \%$ in Finance; and $11.11 \%$ in other industries.

\section{Results}

\section{Hypotheses Testing}

Consistent with Hypothesis 1a, paired-samples $t$-tests found that CEOs were more achievement-motivated than they were affiliation-motivated, $t(89)=22.78, p<.001$. Consistent with Hypothesis 1b, analyses found that CEOs were more power-motivated than affiliation-motivated, $t(89)=21.61, p<.001$. CEOs were similarly achievement- and powermotivated, $t(89)=-1.38, p=.170$ (Figure 1). Consistent with Hypothesis 2, Welch $t$-tests found that, compared with male CEOs, female CEOs were more affiliation-motivated, $t(65.78)=-2.74, p<.01, d=-0.58$, and less power-motivated, $t(86.55)=4.84, p<.001, d=$ 1.02; male and female CEOs were similarly achievement-motivated, $t(77.09)=0.64, p=$ $.524, d=.14$ (Table 1).

\section{Further Analyses}

In exploratory analyses, the study compared mean differences in "objective," accountancy-based (i.e., return on assets, return on equity, and return on investment) and “subjective," stock-based financial performance indicators (i.e., Tobin's Q) amongst male and female CEOs (Haslam et al., 2010; Marinova et al., 2016). There were no clear performance differences between male and female CEOs. However, in interpreting these results, it is important to remember that the present study focused on incumbent CEOs with comparable tenures. 


\section{Discussion}

The present study examined what IM CEOs display in their shareholder letters and whether female and male CEOs differ in their expression of IM. The results showed that, as expected, executives were more likely to display agentic rather than communal motives. This finding suggests that CEOs, regardless of their gender, express motives that are afforded by their social role as a leader. As successful leadership is traditionally expected to require predominantly agentic rather than communal characteristics (Koenig et al., 2011; Vial \& Napier, 2018), leaders seem to seek role-congruency by expressing more achievement and power motivation than affiliation motivation.

Results further showed that female CEOs expressed lower power and higher affiliation motivation than male CEOs. This finding suggests that female leaders display motives congruent with their female gender roles. In addition, male and female CEOs did not differ in their achievement motivation, which is consistent with past IM research by Veroff et al. (1980). Their longitudinal study found that women expressed lower levels of achievement motivation prior to the Women's Movement in the 1960s. This was likely due to societal disapproval of women's achievement motivation in the workplace. However, women's expression of achievement motivation increased, potentially as a result of women's growing participation in the workforce and society's greater approval of women's need for achievement (Veroff et al., 1980).

Women's power motivation, however, may still be proscribed, and their expressions of dominance or self-advocacy tend to be penalized with negative evaluations (e.g., Rudman et al., 2012). Such proscriptions might have contributed to a lower expression of power motivation among female versus male CEOs. Interestingly, most studies from the IM tradition observed that men and women, in general, do not differ in their power motives (Drescher \& Schultheiss, 2016). Now, the question arises as to why the current findings differ 
from prior IM studies that examined gender differences in power motivation (e.g., Pang \& Schultheiss, 2005; Schultheiss \& Brunstein, 2001; Winter, 1988). The predominant focus of earlier research was on analyzing motives in the general population or within student samples. The present study, however, focused on the context of executive leadership. The authors argue that this context may not represent a neutral arousal condition but instead evokes, or "pulls," for the activation of achievement and power motives, which are then increasingly expressed in CEO letters (De Hoogh et al., 2005). It is likely a combination of both higher baseline scores and high arousal conditions that lead to high levels of achievement and power in both sexes, as suggested by Diekman's and Eagly's (2008) notion of a bidirectional relationship between roles and motives. However, due to prevailing gender norms that discourage women from being assertive, the current study suggests that the leadership context may activate the power motive in men more than in women. The authors reason that female CEOs might (consciously or not) balance the demands of their "incompatible" roles by expressing high levels of achievement but also somewhat higher levels of affiliation while inhibiting their power motivation. These findings suggest that both social and gender role norms might influence leaders' motivational displays.

\section{Limitations and Future Research}

Due to the underrepresentation of female CEOs, the present study is limited in its sample size. Future research can address this challenge by extending the data collection to small and medium-sized enterprises, private organizations, or family-led firms. Another option is to focus the analysis on a lower level in the organizational hierarchy and examine female leaders in executive positions more generally. Also, future studies could combine female CEOs from different stock market indices. A second limitation relates to studying IM of CEOs at a distance. The application of the Winter (1994) manual to written materials resulting from archival study designs cannot rule out the possibility that CEOs' explicit 
motives might influence the expression of their IM in the letters. Consequently, it might be argued that impression management tactics on the part of the CEOs could represent an alternative interpretation of the observed differences (Amanatullah \& Morris, 2010). However, the authors argue that (i) the manual's extensive predictive validity and reliability in content-coding IM at a distance (Pang \& Schultheiss, 2005; Winter, 1991b) and (ii) its development from experimentally-derived content analysis systems (Winter, 2010b) justifies its consideration as a best practice approach for coding IM from CEO letters. Nevertheless, future research should aim to replicate current findings using primary CEO data. Moreover, the authors recommend further investigating the relationship between male and female CEOs' IM and leader outcomes. Combining traditional content-coding with new techniques, such as the computerized Linguistic Inquiry and Word Count system (LIWC; Pennebaker et al., 2001) or machine learning algorithms, may prove fruitful for studying IM in larger samples in the future.

\section{Implications}

This research provides insights into the manifestation of IM in male and female CEOs. Simultaneously, this study highlights the relevance of gender roles in the workplace, especially in the leadership context. Interestingly, both male and female CEOs displayed relatively high levels of achievement and power motivation, compared to lower levels of affiliation motivation. Nevertheless, findings indicate that gender roles spill over, leaving their mark on the expression of motivational needs. As long as leadership roles are largely construed as masculine (e.g., Vial \& Napier, 2018), and women are believed and expected to be less agentic than men, women continue to face a double bind. This double bind prevents them from achieving perfect congruence with both roles. However, as Paustian-Underdahl et al. (2014) emphasize, leadership requirements are already changing in line with the demand for more relational qualities, such as collaboration and cooperation (Hogue, 2016; Koenig et 
al., 2011). The authors believe that this development favors women's continued advancement into leadership roles. This, in turn, might bring about changes in (fe)male leaders' selfconstrual as well as societal expectations concerning what IM (fe)male leaders should or should not express. The authors, therefore, assume that, as with the achievement motive, gender differences in CEOs' affiliation and power motives will likely regress. More specifically, motivational profiles may converge towards more androgynous motive patterns (Koenig et al., 2011) consisting of high achievement, high power, and high affiliation motivation, which, according to Spangler and colleagues' (2014) analysis, are the leadership motive patterns of the future.

The authors also argue that the propensity-matched samples of male and female CEOs can generally be considered as similarly successful, as indicated by non-significant mean differences in the financial performance of male- versus female-led firms. Thus, the finding that successful female CEOs display comparatively lower power and higher affiliation motivation than their male counterparts hints at the possibility that expressions of agency in the form of achievement motivation rather than power motivation might benefit female leaders more. Nevertheless, the authors are hesitant to recommend that female leaders try to "manage" the content of CEO letters because it is not clear that such active self-intervention is effective with IM. However, the motivational literature has demonstrated that motive training can be beneficial and has developed several approaches that can help leaders to increase their motivational competence by promoting the congruence of their IM and their motivational self-concepts (see Rheinberg \& Engeser, 2010). The present study and extant research in the motivational literature on motive training thus provide hints on new ways to improve CEO functioning in future coaching and training interventions. At the same time, the authors caution that different motivational expressions may be beneficial in the context of leader emergence versus (strategic) leader effectiveness (McClelland \& Boyatzis, 1982). 
Lastly, the present research, like many other studies in the leadership and gender tradition (see Eagly, 2007; Vecchio, 2002), mainly observed small to medium-sized sex differences in CEOs' motives that can be best understood in terms of overlapping distributions. Therefore, by and large, male and female CEOs may be interpreted as more similar than dissimilar in the IM they express.

\section{Conclusion}

The present study revives and contributes to the debate about what IM manifest in men and women. Current findings challenge the general assumption in the literature that men and women only differ in their affiliation but not in their power motivation. The study provides empirical evidence in line with arguments from the role congruity account of motivation, suggesting that roles are an important motivational force (Diekman \& Eagly, 2008). Specifically, results indicate that CEOs' motivational displays are influenced by both their social role and their gender role in ways that maximize perceived congruence to increase intrapersonal, interpersonal, and economic rewards. 


\section{References}

Amanatullah, E. T., \& Morris, M. W. (2010). Negotiating gender roles: Gender differences in assertive negotiating are mediated by women's fear of backlash and attenuated when negotiating on behalf of others. Journal of Personality and Social Psychology, 98(2), 256-267. https://doi.org/10.1037/a0017094

Amernic, J. H., \& Craig, R. J. (2007). Guidelines for CEO-speak: Editing the language of corporate leadership. Strategy and Leadership, 35(3), 25-31.

https://doi.org/10.1108/10878570710745802

Apers, C., Lang, J. W. B., \& Derous, E. (2019). Who earns more? Explicit traits, implicit motives and income growth trajectories. Journal of Vocational Behavior, 110, 214-228. https://doi.org/10.1016/j.jvb.2018.12.004

Badura, K. L., Grijalva, E., Newman, D. A., Yan, T. T., \& Jeon, G. (2018). Gender and leadership emergence: A meta-analysis and explanatory model. Personnel Psychology, 71(3), 335-367. https://doi.org/10.1111/peps.12266

Bakan, D. (1966). The duality of human existence: An essay on psychology and religion. Rand McNally.

Bark, A. S. H., Escartín, J., Schuh, S. C., \& van Dick, R. (2016). Who leads more and why? A mediation model from gender to leadership role occupancy. Journal of Business Ethics, 139(3), 473-483. https://doi.org/10.1007/s10551-015-2642-0

Bhojraj, S., \& Lee, C. M. C. (2002). Who is my peer? A valuation-based approach to the selection of comparable firms. Journal of Accounting Research, 40(2), 407-439. https://doi.org/10.1111/1475-679X.00054

Bosak, J., Kulich, C., Rudman, L., \& Kinahan, M. (2018). Be an advocate for others, unless you are a man: Backlash against gender-atypical male job candidates. Psychology of Men \& Masculinity, 19(1), 156-165. https://doi.org/10.1037/men0000085 
Bosak, J., Sczesny, S., \& Eagly, A. H. (2012). The impact of social roles on trait judgments: A critical reexamination. Personality and Social Psychology Bulletin, 38(4), 429-440. https://doi.org/10.1177/0146167211427308

Brunstein, J. C., Schultheiss, O. C., \& Grässman, R. (1998). Personal goals and emotional well-being: The moderating role of motive dispositions. Journal of Personality and Social Psychology, 75(2), 494-508. https://doi.org/10.1037/0022- 3514.75.2.494

Bussey, K., \& Bandura, A. (1999). Social cognitive theory of gender development and differentiation. Psychological Review, 106(4), 676-713. https://doi.org/10.1037/0033295X.106.4.676

Catalyst. (2020, January 15). Pyramid: Women in $S \& P 500$ companies. https://www.catalyst.org/research/women-in-sp-500-companies/

Chusmir, L. H., \& Azevedo, A. (1992). Motivation needs of sampled Fortune-500 CEOs: Relations to organization outcomes. Perceptual and Motor Skills, 75(2), 595-612. https://doi.org/10.2466/pms.1992.75.2.595

Connelly, B. S., Sackett, P. R., \& Waters, S. D. (2013). Balancing treatment and control groups in quasi-experiments: An introduction to propensity scoring. Personnel Psychology, 66(2), 407-442. https://doi.org/10.1111/peps.12020

Cornelius, E. T., \& Lane, F. B. (1984). The power motive and managerial success in a professionally oriented service industry organization. Journal of Applied Psychology, 69(1), 32-39. https://doi.org/10.1037/0021-9010.69.1.32

De Hoogh, A. H. B., Den Hartog, D. N., Koopman, P. L., Thierry, H., Van den Berg, P. T., Van der Weide, J. G., \& Wilderom, C. P. M. (2005). Leader motives, charismatic leadership, and subordinates' work attitude in the profit and voluntary sector. Leadership Quarterly, 16(1), 17-38. https://doi.org/10.1016/j.leaqua.2004.10.001 Delbecq, A., House, R. J., de Luque, M. S., \& Quigley, N. R. (2013). Implicit motives, 
leadership, and follower outcomes: An empirical test of CEOs. Journal of Leadership and Organizational Studies, 20(1), 7-24. https://doi.org/10.1177/1548051812467207

Denzinger, F., Backes, S., Job, V., \& Brandstätter, V. (2016). Age and gender differences in implicit motives. Journal of Research in Personality, 65, 52-61. https://doi.org/10.1016/j.jrp.2016.09.003

Diekman, A. B., \& Eagly, A. H. (2008). Of men, women, and motivation: A role congruity account. In J. Y. Shah \& W. L. Gardner (Eds.), Handbook of motivation science (pp. 434-447). Guilford Press.

Drescher, A., \& Schultheiss, O. C. (2016). Meta-analytic evidence for higher implicit affiliation and intimacy motivation scores in women, compared to men. Journal of Research in Personality, 64, 1-10. https://doi.org/10.1016/j.jrp.2016.06.019

Duehr, E. E., \& Bono, J. E. (2006). Men, women, and managers: Are stereotypes finally changing? Personnel Psychology, 59(4), 815-846. https://doi.org/10.1111/j.1744$6570.2006 .00055 . x$

Duncan, L. E., \& Peterson, B. E. (2010). Gender and motivation for achievement, affiliationintimacy, and power. In J. C. Chrisler \& D. R. McCreary (Eds.), Handbook of gender research in psychology (Vol. 63, Issue 1, pp. 41-62). Springer. https://doi.org/10.1007/978-1-4419-1467-5_3

Eagly, A. H. (2000). Gender roles. In A. E. Kazdin (Ed.), Encyclopedia of psychology (Vol. 3, pp. 448-453). APA Books.

Eagly, A. H. (2007). Female leadership advantage and disadvantage: Resolving the contradictions. Psychology of Women Quarterly, 31(1), 1-12. https://doi.org/10.1111/j.1471-6402.2007.00326.x

Eagly, A. H., \& Antonakis, J. (2015). Leadership. In M. Mikulincer, P. R. Shaver, E. Borgida, \& J. A. Bargh (Eds.), APA handbooks in psychology. APA handbook of 
personality and social psychology, Vol. 1. Attitudes and social cognition (pp. 571-592). APA Books.

Eagly, A. H., \& Karau, S. J. (2002). Role congruity theory of prejudice toward female leaders. Psychological Review, 109(3), 573-598. https://doi.org/10.1037/0033295X.109.3.573

Eagly, A. H., Makhijani, M. G., \& Klonsky, B. G. (1992). Gender and the evaluation of leaders: A meta-analysis. Psychological Bulletin, 111(1), 3-22. https://doi.org/10.1037/0033-2909.111.1.3

Eagly, A. H., Wood, W., \& Diekman, A. B. (2000). Social role theory of sex differences and similarities: A current appraisal. In T. Eckes \& H. M. Trautner (Eds.), The developmental social psychology of gender (pp. 123-174). Erlbaum.

Elprana, G., Felfe, J., Stiehl, S., \& Gatzka, M. (2015). Exploring the sex difference in affective motivation to lead: Furthering the understanding of women's underrepresentation in leadership positions. Journal of Personnel Psychology, 14(3), 142-152. https://doi.org/10.1027/1866-5888/a000137

Fama, E. F., \& French, K. R. (1997). Industry costs of equity. Journal of Financial Economics, 43(2), 153-193. https://doi.org/10.1016/S0304-405X(96)00896-3

French, K. R. (2019, January 14). Detail for 12 industry portfolios. Kenneth R. French. https://mba.tuck.dartmouth.edu/pages/faculty/ken.french/Data_Library/det_12_ind_port. html

Gardner, W. L., \& Gabriel, S. (2004). Gender differences in relational and collective interdependence: Implications for self-views, social behavior, and subjective wellbeing. In A. H. Eagly, A. E. Beall, \& R. J. Sternberg (Eds.), The psychology of gender (2nd ed., pp. 169-191). Guilford Press.

Geis, F. L. (1993). Self-fulfilling prophecies: a social psychological view of gender. In A. E. 
Beall \& R. J. Sternberg (Eds.), The psychology of gender (pp. 9-54). Guilford Press.

Gutek, B. A., \& Morasch, B. (1982). Sex-ratios, sex-role spillover, and sexual harassment of women at work. Journal of Social Issues, 38(4), 55-74. https://doi.org/10.1111/j.15404560.1982.tb01910.x

Hambrick, D. C., \& Quigley, T. J. (2014). Toward more accurate contextualization of the CEO effect on firm performance. Strategic Management Journal, 35(4), 473-491. https://doi.org/10.1002/smj.2108

Haslam, S. A., Ryan, M. K., Kulich, C., Trojanowski, G., \& Atkins, C. (2010). Investing with prejudice: The relationship between women's presence on company boards and objective and subjective measures of company performance. British Journal of Management, 21(2), 484-497. https://doi.org/10.1111/j.1467-8551.2009.00670.x

Hoffman, B. J., Woehr, D. J., Maldagen-Youngjohn, R., \& Lyons, B. D. (2011). Great man or great myth? A quantitative review of the relationship between individual differences and leader effectiveness. Journal of Occupational and Organizational Psychology, 84(2), 347-381. https://doi.org/10.1348/096317909X485207

Hogue, M. (2016). Gender bias in communal leadership: Examining servant leadership. Journal of Managerial Psychology, 31(4), 837-849. https://doi.org/10.1108/JMP-102014-0292

Holmes, M. (2008). Gender and everyday life. Routledge. https://doi.org/10.4324/9780203929384

Hoobler, J. M., Masterson, C. R., Nkomo, S. M., \& Michel, E. J. (2018). The business case for women leaders: Meta-analysis, research critique, and path forward. Journal of Management, 44(6), 2473-2499. https://doi.org/10.1177/0149206316628643

House, R. J., Spangler, W. D., \& Woycke, J. (1991). Personality and charisma in the U.S. presidency: A psychological theory of leader effectiveness. Administrative Science 
Quarterly, 36(3), 364-396. https://doi.org/10.2307/2393201

Jacobs, R. L., \& McClelland, D. C. (1994). Moving up the corporate ladder: A longitudinal study of the leadership motive pattern and managerial success in women and men. Consulting Psychology Journal: Practice and Research, 46(1), 32-41. https://doi.org/10.1037/1061-4087.46.1.32

Kanfer, R., Frese, M., \& Johnson, R. E. (2017). Motivation related to work: A century of progress. Journal of Applied Psychology, 102(3), 338-355. https://doi.org/10.1037/ap10000133

Kehr, H. M. (2004). Integrating implicit motives, explicit motives, and perceived abilities: The compensatory model of work motivation and volition. The Academy of Management Review, 29(3), 479-499. https://doi.org/10.2307/20159055

Kirkpatrick, S. A., Wofford, J. C., \& Baum, J. R. (2002). Measuring motive imagery contained in the vision statement. Leadership Quarterly, 13(2), 139-150. https://doi.org/10.1016/S1048-9843(02)00096-6

Koenig, A. M., Eagly, A. H., Mitchell, A. A., \& Ristikari, T. (2011). Are leader stereotypes masculine? A meta-analysis of three research paradigms. Psychological Bulletin, 137(4), 616-642. https://doi.org/10.1037/a0023557

Koo, T. K., \& Li, M. Y. (2016). A guideline of selecting and reporting intraclass correlation coefficients for reliability research. Journal of Chiropractic Medicine, 15(2), 155-163. https://doi.org/10.1016/j.jcm.2016.02.012

Kunkel, A., Dennis, M. R., \& Waters, E. (2003). Contemporary university students' ratings of characteristics of men, women, and CEOs. Psychological Reports, 93(3), 1197-1213. https://doi.org/10.2466/pr0.2003.93.3f.1197

Lang, J. W. B. (2014). A dynamic Thurstonian item response theory of motive expression in the picture story exercise: Solving the internal consistency paradox of the PSE. 
Psychological Review, 121(3), 481-500. https://doi.org/10.1037/a0037011

Lang, J. W. B., Zettler, I., Ewen, C., \& Hülsheger, U. R. (2012). Implicit motives, explicit traits, and task and contextual performance at work. Journal of Applied Psychology, 97(6), 1201-1217. https://doi.org/10.1037/a0029556

Locke, K. D. (2015). Agentic and communal social motives. Social and Personality Psychology Compass, 9(10), 525-538. https://doi.org/10.1111/spc3.12201

Marinova, J., Plantenga, J., \& Remery, C. (2016). Gender diversity and firm performance: evidence from Dutch and Danish boardrooms. International Journal of Human Resource Management, 27(15), 1777-1790. https://doi.org/10.1080/09585192.2015.1079229

McClelland, D. C., \& Boyatzis, R. E. (1982). Leadership motive pattern and long-term success in management. Journal of Applied Psychology, 67(6), 737-743. https://doi.org/10.1037/0021-9010.67.6.737

McClelland, D. C, \& Burnham, D. H. (2003, January). Power is the great motivator. Harvard Business Review, 81(1), 117-126. https://hbr.org/2003/01/power-is-the-great-motivator (Reprinted from "Power is the great motivator," 1976, Harvard Business Review, 25[3/4], 159-166.)

McClelland, D. C., Koestner, R., \& Weinberger, J. (1989). How do self-attributed and implicit motives differ? Psychological Review, 96(4), 690-702. https://doi.org/10.1037/0033-295X.96.4.690

McClelland, D. C., \& Pilon, D. A. (1983). Sources of adult motives in patterns of parent behavior in early childhood. Journal of Personality and Social Psychology, 44(3), 564574. https://doi.org/10.1037/0022-3514.44.3.564

Pang, J. S., \& Baumann, N., (in press). At the crossroads of women's experience: Insights from and intersections between motivation, emotion, gender, and culture. In F. M. Cheung \& D. F. Halpern (Eds.), The Cambridge international handbook on psychology 
of women (pp. 1-38). Cambridge University Press.

Pang, J. S., \& Schultheiss, O. C. (2005). Assessing implicit motives in U.S. college students:

Effects of picture type and position, gender and ethnicity, and cross-cultural

comparisons. Journal of Personality Assessment, 85(3), 280-294.

https://doi.org/10.1207/s15327752jpa8503_04

Paustian-Underdahl, S. C., Walker, L. S., \& Woehr, D. J. (2014). Gender and perceptions of leadership effectiveness: A meta-analysis of contextual moderators. Journal of Applied Psychology, 99(6), 1129-1145. https://doi.org/10.1037/a0036751

Pennebaker, J. W., Francis, M. E., \& Booth, R. J. (2001). Linguistic inquiry and word count: LIWC 2001. Lawrence Erlbaum Associates.

Powell, G. N., Butterfield, D. A., \& Parent, J. D. (2002). Gender and managerial stereotypes: Have the times changed? Journal of Management, 28(2), 177-193.

https://doi.org/10.1177/014920630202800203

Ramalingegowda, S., \& Yu, Y. (2012). Institutional ownership and conservatism. Journal of Accounting and Economics, 53(1/2), 98-114.

https://doi.org/10.1016/j.jacceco.2011.06.004

Rheinberg, F., \& Engeser, S. (2010). Motive training and motivational competence. In O. C. Schultheiss \& J. C. Brunstein (Eds.), Implicit motives (pp. 510-548). Oxford University Press.

Ridgeway, C. L., \& Correll, S. J. (2004). Unpacking the gender system: A theoretical perspective on gender beliefs and social relations. Gender \& Society, 18(4), 510-531. https://doi.org/10.1177/0891243204265269

Rosette, A. S., \& Tost, L. P. (2010). Agentic women and communal leadership: How role prescriptions confer advantage to top women leaders. Journal of Applied Psychology, 95(2), 221-235. https://doi.org/10.1037/a0018204 
Roter, D. L., Hall, J. A., \& Aoki, Y. (2002). Physician gender effects in medical communication: A meta-analytic review. Journal of the American Medical Association, 288(6), 756-764. https://doi.org/10.1001/jama.288.6.756

Rudman, L. A., Moss-Racusin, C. A., Phelan, J. E., \& Nauts, S. (2012). Status incongruity and backlash effects: Defending the gender hierarchy motivates prejudice against female leaders. Journal of Experimental Social Psychology, 48(1), 165-179. https://doi.org/10.1016/j.jesp.2011.10.008

Runge, J. M., \& Lang, J. W. B. (2019). Can people recognize their implicit thoughts? The motive self-categorization test. Psychological Assessment, 31(7), 939-951. https://doi.org/10.1037/pas0000720

Schuh, S. C., Bark, A. S. H., Van Quaquebeke, N., Hossiep, R., Frieg, P., \& Van Dick, R. (2014). Gender differences in leadership role occupancy: The mediating role of power motivation. Journal of Business Ethics, 120(3), 363-379. https://doi.org/10.1007/s10551-013-1663-9

Schultheiss, O. C. (2013). The hormonal correlates of implicit motives. Social and Personality Psychology Compass, 7(1), 52-65. https://doi.org/10.1111/spc3.12008

Schultheiss, O. C., \& Brunstein, J. C. (2001). Assessment of implicit motives with a research version of the TAT: Picture profiles, gender differences, and relations to other personality measures. Journal of Personality Assessment, 77(1), 71-86. https://doi.org/10.1207/S15327752JPA7701_05

Schultheiss, O. C., \& Brunstein, J. C. (2010). Implicit motives. Oxford University Press. https://doi.org/10.1093/acprof:oso/9780195335156.001.0001

Schultheiss, O. C., \& Pang, J. C. (2007). Measuring implicit motives. In R. W. Robins, R. C. Fraley, \& R. Krueger (Eds.), Handbook of research methods in personality psychology (pp. 322-344). Guilford Press. 
Shackelford, S., Wood, W., \& Worchel, S. (1996). Behavioral styles and the influence of women in mixed-sex groups. Social Psychology Quarterly, 59(3), 284-293. https://doi.org/10.2307/2787024

Shrout, P. E., \& Fleiss, J. L. (1979). Intraclass correlations: Uses in assessing rater reliability. Psychological Bulletin, 86(2), 420-428. https://doi.org/10.1037/0033-2909.86.2.420

Sorrentino, R. M. (1973). An extension of theory of achievement motivation to the study of emergent leadership. Journal of Personality and Social Psychology, 26(3), 356-368. https://doi.org/10.1037/h0034476

Spangler, W. D., \& House, R. J. (1991). Presidential effectiveness and the leadership motive profile. Journal of Personality and Social Psychology, 60(3), 439-455. https://doi.org/10.1037/0022-3514.60.3.439

Spangler, W. D., Tikhomirov, A., Sotak, K. L., \& Palrecha, R. (2014). Leader motive profiles in eight types of organizations. Leadership Quarterly, 25(6), 1080-1094. https://doi.org/10.1016/j.leaqua.2014.10.001

Standard \& Poor's Compustat (2019). Compustat capital IQ - fundamentals annual. Wharton Research Data Services. Retrieved November 11, 2019, from https://wrdsweb.wharton.upenn.edu/wrds/index.cfm

Standard \& Poor's Execucomp (2019). Compustat executive compensation - annual compensation. Wharton Research Data Services. Retrieved January 14, 2019, from https://wrds-web.wharton.upenn.edu/wrds/index.cfm

Steinmann, B., Dörr, S. L., Schultheiss, O. C., \& Maier, G. W. (2015). Implicit motives and leadership performance revisited: What constitutes the leadership motive pattern? Motivation and Emotion, 39(2), 167-174. https://doi.org/10.1007/s11031-014-9458-6

Thoemmes, F. (2012, January 30). Propensity score matching in SPSS. ArXiv.Org. http://arxiv.org/abs/1201.6385 
Twenge, J. M. (1997). Changes in masculine and feminine traits over time: A meta-analysis. Sex Roles, 36(5/6), 305-325. https://doi.org/10.1007/BF02766650

Vecchio, R. P. (2002). Leadership and gender advantage. The Leadership Quarterly, 13(6), 643-671. https://doi.org/10.1016/S1048-9843(02)00156-X

Veenstra, K. J. (2013, May 1). CEO implicit motives: Their impact on firm investment and firm performance. SSRN Electronic Journal. https://doi.org/10.2139/ssrn.2258530

Veroff, J., Depner, C., Kulka, R., \& Douvan, E. (1980). Comparison of American motives: 1957 versus 1976. Journal of Personality and Social Psychology, 39(6), 1249-1262. https://doi.org/10.1037/h0077729

Vial, A. C., \& Napier, J. L. (2018). Unnecessary frills: Communality as a nice (but expendable) trait in leaders. Frontiers in Psychology, 9(10), 1-15. https://doi.org/10.3389/fpsyg.2018.01866

Watson, C. (1988). When a woman is the boss: Dilemmas in taking charge. Group \& Organization Management, 13(2), 163-181. https://doi.org/10.1177/105960118801300204

Williams, M. J., \& Tiedens, L. Z. (2016). The subtle suspension of backlash: A meta-analysis of penalties for women's implicit and explicit dominance behavior. Psychological Bulletin, 142(2), 165-197. https://doi.org/10.1037/bul0000039

Winter, D. G. (1987). Leader appeal, leader performance, and the motive profiles of leaders and followers: A study of American presidents and elections. Journal of Personality and Social Psychology, 52(1), 196-202. https://doi.org/10.1037/0022-3514.52.1.196

Winter, D. G. (1988). The power motive in women-and men. Journal of Personality and Social Psychology, 54(3), 510-519. https://doi.org/10.1037/0022-3514.54.3.510

Winter, D. G. (1991a). A motivational model of leadership: Predicting long-term management success from TAT measures of power motivation and responsibility. The 
Leadership Quarterly, 2(2), 67-80. https://doi.org/10.1016/1048-9843(91)90023-U

Winter, D. G. (1991b). Measuring personality at a distance: Development of an integrated system for scoring motives in running text. In A. J. Stewart, J. M. Healy, Jr., \& D. Ozer (Eds.), Perspectives in personality: Approaches to understanding lives (pp. 59-89). Jessica Kingsley.

Winter, D. G. (1994). Manual for scoring motive imagery in running text (version 4.2) [Unpublished Manuscript]. Department of Psychology, University of Michigan, Ann Arbor, MI.

Winter, D. G. (2010a). Why achievement motivation predicts success in business but failure in politics: The importance of personal control. Journal of Personality, 78(6), 16371668. https://doi.org/10.1111/j.1467-6494.2010.00665.x

Winter, D. G. (2010b). Political and historical consequences of implicit motives. In O. C. Schultheiss \& J. Brunstein (Eds.), Implicit motives (pp. 407-432). Oxford University Press. https://doi.org/10.1093/acprof:oso/9780195335156.003.0014

Wojciszke, B., Abele, A. E., \& Baryla, W. (2009). Two dimensions of interpersonal attitudes: Liking depends on communion, respect depends on agency. European Journal of Social Psychology, 39(6), 973-990. https://doi.org/10.1002/ejsp.595

Yuan, M. (2017, April 24). What and how the firm features determine CEO equity-based compensation? SSRN Electronic Journal. https://doi.org/10.2139/ssrn.2957308. 
Tables

Table 1

Gender differences in CEOs' implicit motives and financial performance measures.

\begin{tabular}{|c|c|c|c|c|c|c|c|c|}
\hline \multirow[b]{2}{*}{ Variable } & \multicolumn{2}{|c|}{$M(S D)$} & \multirow[b]{2}{*}{ Cohen's $d$} & \multicolumn{3}{|c|}{$t$-test } & \multicolumn{2}{|c|}{ MANOVA } \\
\hline & Female & Male & & $t$ & $d f$ & $p$ & $F(1,85)$ & $p$ \\
\hline \multicolumn{9}{|l|}{ Implicit motives } \\
\hline Achievement & $10.83(3.69)$ & $11.26(2.48)$ & 0.14 & 0.64 & 77.09 & .524 & 1.41 & .239 \\
\hline Power & $10.14(2.82)$ & $13.23(3.22)$ & 1.02 & 4.84 & 86.55 & .000 & $23.58 * *$ & .000 \\
\hline Affiliation & $3.16(2.41)$ & $2.05(1.24)$ & -0.58 & -2.74 & 65.78 & .008 & $8.09 *$ & .006 \\
\hline \multicolumn{9}{|c|}{ Financial performance measures } \\
\hline Return on assets & $0.06(0.06)$ & $0.05(0.05)$ & -0.18 & -0.99 & 85.17 & .327 & 0.9 & .344 \\
\hline Return on equity & $0.13(0.52)$ & $0.05(0.06)$ & -0.22 & -1.13 & 44.31 & .265 & 1.25 & .268 \\
\hline Return on investment & $0.11(0.11)$ & $0.08(0.08)$ & -0.31 & -1.54 & 80.27 & .128 & 2.23 & .139 \\
\hline Tobin's Q & $1.75(1.01)$ & $1.78(0.85)$ & 0.03 & 0.17 & 83.59 & .869 & 0.07 & .796 \\
\hline
\end{tabular}

Note: $N=87-90$ CEOs (43-45 male). All outcome variables were computed using the S\&P Compustat (2019) database at years' end two years after CEO appointment. Return on assets, equity, and investment are presented in million dollars. Return on assets, return on equity, return on investment, and Tobin's Q were estimated using the formulas provided in Yuan (2017) and Ramalingegowda and Yu (2012).

$* \mathrm{p}<.01 * * \mathrm{p}<.001$ 
Figures

Figure 1

Gender differences in CEOs' implicit motives

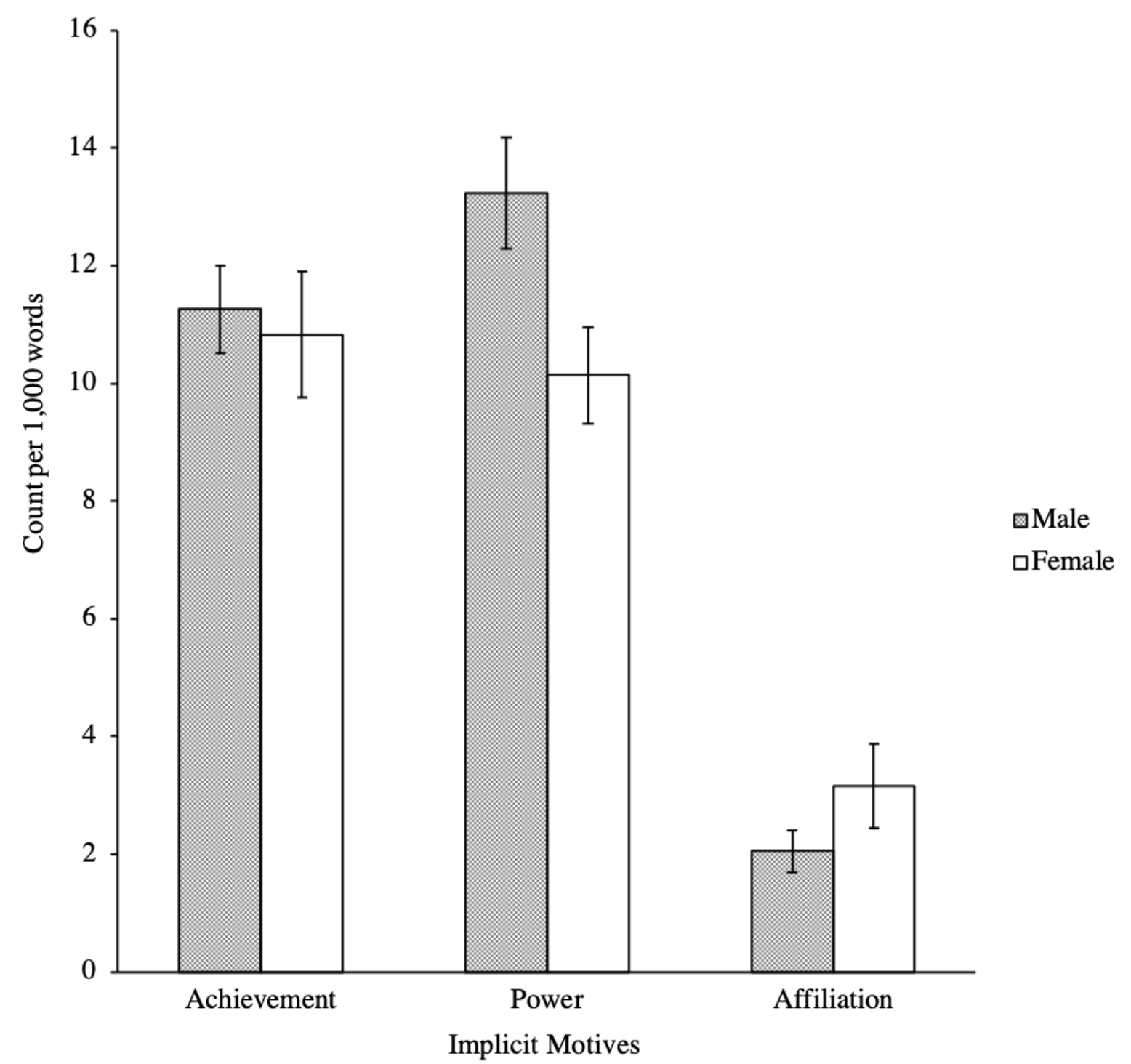

Note. Means and 95\% confidence intervals of the implicit achievement, power, and affiliation motives of 45 male and 45 female CEOs per 1,000 words. 